\title{
Plantibodies: A New Approach for Immunomodulation in Human Health
}

\author{
Himani Punia ${ }^{1}$ and Anurag Malik*2 \\ ${ }^{1}$ Department of Chemistry \& Biochemistry, India \\ ${ }^{2}$ Department of Seed Science \& Technology, India
}

Received: 制: November 04, 2018; Published: 制: November 19, 2018

*Corresponding author: Anurag Malik, Department of Seed Science \& Technology, India

\section{Introduction}

Antibodies or immunoglobulins are the vital component of adaptive immune system in mammals. These are mainly present in the body fluid and constitute an assembly of glycoproteins released by B-cells. B-cells constitute the humoral type of adaptive immune system. They are highly specific their mode of action. First they recognize their target specifically, binds to the antigen/toxin of pathogen and produce and elicit the immune response. These features permit immunoglobulins to be employed in diverse range of applications such as diagnosis, prevention and treatment [1]. Production of defective antibody response results in increased vulnerability to pyogenic infections due to impairment in B-cell function, e.g. in hyper-IgM syndrome as a result of improper signaling between $\mathrm{B}$ and $\mathrm{T}$ cells and in X-linked agammaglobulinemia. To overcome these defects, constant region of a human immunoglobulin is modified by transgenic approach to create recombinant antibody [2]. With this advancement, a new expectation of a reliable, inexpensive cure for diseases like, diabetes and cancer was awakening; but the major drawback was its cost ineffectiveness.

Hence, production of cost-effective and scalable platforms that is safe for therapeutics is urgently required [3]. Transgenics is one of the most potential applications in therapeutics for the preparation of various biological substances such as antibodies, proteins and vaccines. They can be produced from plants by transforming antibody-coding genes from humans to plants as 'transgene'. Plants acts as suitable host for production of antibodies referred as "plantibodies". The term "plantibodies" describes plant based products which contained antibody and its fragments; produced by genetically engineering. Hence, plants are largely used as a host or bioreactors by exploiting their endomembrane and secretory system to generate huge amount of biological proteins of clinical importance (either full-length or smaller length fragments). This opens a new era in plant biology research. A wide variety of plants functionally expressed different types of recombinant by exploiting the same pathway for the assembly of heavy chain and light chain signal peptides followed by proper folding and assembly as in mammalian cells [4].

Benefits of Using Plants as Host For Mammalian Antibody Production

Plantibodies functions in a similar way to mammalian antibodies. It offers numerous unique advantages over conventional methods. Firstly, plants are less prone to mammalian pathogens; this property reduces screening costs for bacterial toxins, prions and viruses. Both plants and humans have a similar endomembrane and secretory pathway system. Secondly, plants are widely distributed; their maturation time completes in a short period of time, say for example, in one season; which enables their production in a short period of time. Hence they are the cost-effective compared to their animal counterparts [5]. Exposure to mammalian antibodies do not trigger plants immune response compared as compared to mammalian system. Production of large amount of antibodies, comparatively in short time period is the most fascinating benefit of plants as host [6]. Comparatively, crops, for example, corn and tobacco which have higher biomass may act as good candidate in genetic engineering process; where biological products and viable proteins (stored in seed for an indefinite period) will be produced in large amounts with small decline in their catalytic activity [5].

Plants viz. corn, tobacco, soybean and other crops shows potential alternative for production of therapeutic proteins. Crops having maximum biomass/hectare such as alfalfa and tobacco may be a best alternative for antibodies production. Tobacco, a non-feed 
crop proves to be the most potential crop for large scale production of therapeutic antibodies. In transgenic tobacco, antibodies against melanoma, human papillomavirus, B-cell lymphoma, colon, testicular have been produced. These tobacco based plantibodies are still under progress for commercial use in human health.

\section{Uses of Plantibodies in Medicine}

Genetically engineered plants/transgenic plants used as host for plantibodies production represents a huge prospect for the pharmaceuticals. Among all the pharmaceutical compounds, maximum contribution is accompanied by recombinant proteins. Presently, clinical trials are going on a number of plantibodies for their therapeutic role. In therapeutics, CaroRx® was the first plantibody produced from tobacco. It is anti-Streptococcus mutans secretory antibody and protects from dental caries. Another plantibody was developed in soybean against herpes simplex virus [7]. USDA has approved CaroRx®, a plantibody for humans; expressed in tobacco, against poultry virus [8]. Plants expressing clinical proteins and polypeptides of pharmaceutical importance such as human C protein, interferons, hormones, and cytokines are currently used to provide immunization for example, oral immunization. Edible vaccines expressed in edible tissue of plants have proved to be an excellent source for expression of desirable antigens and their fragments. This is a cost effective method to provide immunization via. oral mean. Combining these, genetically engineered plants proved to be superior system for vaccination in humans. Recently, antibodies against Ebola virus infection has been explored in tobacco (Nicotiana benthamiana).

\section{Conclusion}

Genetically engineered plants acts as most desirable and promising host for expression of plantibodies for humans. They

ISSN: 2574-1241

DOI: 10.26717/BJSTR.2018.11.002061

Anurag Malik. Biomed J Sci \& Tech Res

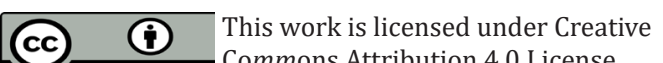

Submission Link: https://biomedres.us/submit-manuscript.php stably express antibodies and its fragments and edible vaccines in their edible tissues which are of therapeutic importance. Highscalability, low-cost and safety characteristics present an attractive approach for commercialization of pharmaceutical products for the developing world.

\section{References}

1. Andersen DC, Krummen L (2002) Recombinant protein expression for therapeutic applications. Current Opinion in Biotechnology 13(2): 117123.

2. Fischer R, Richard MT, Schillberg S (2003) Production of antibodies in plants and their use for global health. Vaccine 21(7): 820-825.

3. Hood EE, Woodard Si, Horn ME (2002) Monoclonal antibody manufacturing in transgenic plants - myths and realities. Current Opinion in Biotechnology 13(6): 630-635.

4. Lai H, Engle M, Fuchs A, Keller T, Johnson S, et al. (2010) Monoclonal antibody produced in plants efficiently treats West Nile virus infection in mice. PNAS 107(6): 2419-2424.

5. Morrison SL, Johnson MJ, Herzenberg LA, Oi VT (1984) Chimeric human antibody molecules mouse antigenbinding domains with human constant region domains. Proceedings in Natural Academy of Science, USA 81(21): 6851-6855.

6. Sharma AK, Jani D, Raghunath C, Tyagi AK (2004) Transgenic plants as bioreactors. Indian Journal of Biotechnology 3: 274-290.

7. Vermij P, Waltz E (2006) USDA approves the first plantbased vaccine. Nature Biotechnology 24(3): 233-234.

8. Zeitlin L, Olmsted SS, Moench TR, Co MS, Martinell BJ, et al. (1998) A humanized monoclonal antibody produced in transgenic plants for immunoprotection of the vagina against genital herpes. Nature Biotechnology 16(13): 1361-1364.

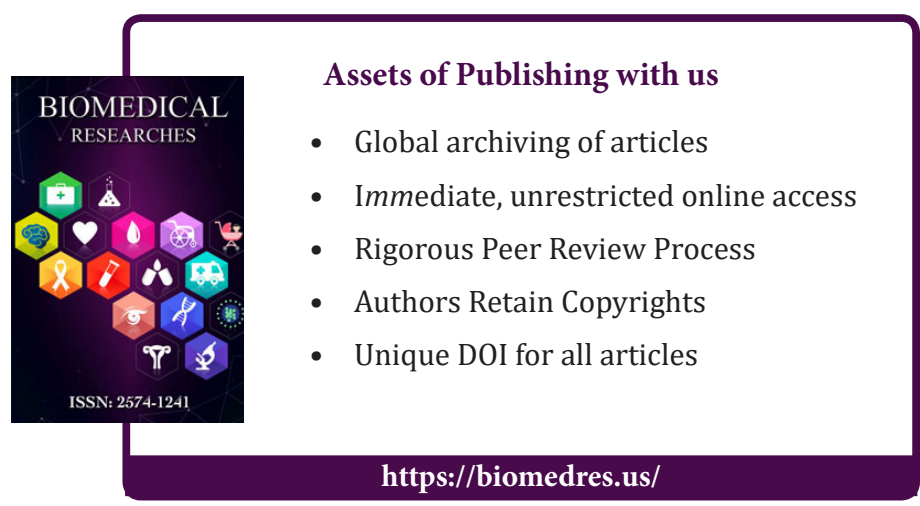

Cite this article: Himani Punia, Anurag Malik. Plantibodies: A New Approach for Immunomodulation in Human Health. Biomed J Sci \& Tech Res 11(2)-2018.BJSTR. MS.ID.002061. DOI: 10.26717/ BJSTR.2018.11.002061. 